\title{
Resolution of Failed Banks by Deposit Insurers Cross-Country Evidence
}

\section{Thorsten Beck and Luc Laeven*}

\begin{abstract}
There is a wide cross-country variation in the institutional structure of bank failure resolution, including the role of the deposit insurer. We use quantitative analysis for 57 countries and discussion of specific country cases to illustrate this variation. Using data for over 1,700 banks across 57 countries, we show that banks in countries where the deposit insurer has the responsibility of intervening failed banks and the power to revoke membership in the deposit insurance scheme are more stable and less likely to become insolvent. Involvement of the deposit insurer in bank failure resolution thus dampens the negative effect that deposit insurance has on banks' risk taking.
\end{abstract}

JEL Classifications: G21, G28, G30

Keywords: bank fragility; bank failure resolution; deposit insurance

World Bank Policy Research Working Paper 3920, May 2006

The Policy Research Working Paper Series disseminates the findings of work in progress to encourage the exchange of ideas about development issues. An objective of the series is to get the findings out quickly, even if the presentations are less than fully polished. The papers carry the names of the authors and should be cited accordingly. The findings, interpretations, and conclusions expressed in this paper are entirely those of the authors. They do not necessarily represent the view of the World Bank, its Executive Directors, or the countries they represent. Policy Research Working Papers are available online at http://econ.worldbank.org.

* Beck is at the World Bank and Laeven is at the World Bank and CEPR. Corresponding author: Thorsten Beck, World Bank, TBeck@worldbank.org, Phone: (202) 473-3215, Fax: (202) 522-1155. We would like to thank Asli Demirguc-Kunt and Ross Levine for very useful comments and Baybars Karacaovali for excellent research assistance. 


\section{Introduction}

There is a broad variation in countries' framework and practice to resolve failing banks. Some countries rely on the court system to declare banks insolvent and to resolve them. Other countries have delegated the power to resolve failing banks almost completely to bank supervisors with little if any judicial recourse (see Hüpkes, 2004, and Beck, 2004, for a discussion of differences in bank failure resolution schemes across countries). There is also variation in the degree to which bank failure resolution interacts with deposit insurance, which is another increasingly popular component of the financial safety net. In some countries, such as Brazil, the deposit insurer is set up as a paybox with the function to pay out depositors of failed banks, while in other countries, such as the United States, the deposit insurer not only has important supervisory functions, but has the lead role in resolving failing banks.

Resolving weak banks efficiently can have important repercussions for financial and economic development. Honohan and Klingebiel (2003) estimate the average fiscal cost of banking crisis resolution at 13\% of GDP, while Claessens, Klingebiel and Laeven (2003) show that different approaches to resolving banking crises have led to very different outcomes in terms of recovery of economic growth after the crisis. But even the failure of individual banks can imply large financial and economic costs for depositors, borrowers and taxpayers, as the failure of institutions such as the Bank of Credit and Commerce International (BCCI) has shown (see Bartholomew and Gup, 1997, for an overview of bank failures across non-US G10 countries).

While there is a large theoretical and empirical literature on the insolvency and resolution of non-financial corporations, the literature on financial corporation distress has focused mostly on systemic banking crises, i.e. the determinants and resolution strategies for wide-spread bank 
failures, rather than on the efficient resolution of idiosyncratic bank failures. ${ }^{1}$ Similarly, while there is a large theoretical and empirical literature on the relationship between deposit insurance and bank fragility, its link with bank failure resolution has not been empirically explored. ${ }^{2}$ While policy makers' attention has recently shifted to the non-systemic resolution of idiosyncratic bank failures, up to date there is no cross-country evidence on its optimal design. ${ }^{3}$ In this paper we assess empirically the relationship between the design of bank failure resolution arrangements and bank fragility. Specifically, this paper addresses two questions: First, is a bank failure resolution system that relies more on the deposit insurer more conducive to market discipline? Second, which institutional structure of a deposit insurer involved in bank failure resolution is most conducive to bank stability?

There is little disagreement that banks need special insolvency rules compared to nonfinancial corporations (Hüpkes, 2004). Their role in transforming maturity, i.e. transforming short-term deposits into medium to long-term loans, makes banks more sensitive to short-term liquidity shortages that ultimately could result in bank runs (Diamond and Dybvig, 1983). Specifically, an interruption of the access to their savings in the failed bank can cause depositors to panic and run on other, fundamentally sound, banks. Furthermore, the information value of an ongoing credit relationship, which serves as the basis for debtor discipline and access to credit, decreases substantially in the case of failing banks. Finally, banks' critical role in market-based economies - providing payment services and intermediating society's savings - and their role in

\footnotetext{
${ }^{1}$ For a discussion of the resolution of bankruptcy of non-financial corporations, see Gilson, Hotchkiss and Ruback (2000), Hart (2000), Wihlborg et al. (2001) and Claessens and Klapper (2005). For resolution strategies of systemic banking crises, we refer to Claessens, Djankov and Klapper (2003) and Honohan and Laeven (2005), among others. ${ }^{2}$ See, for example, Demirguc-Kunt and Detragiache (2002) on the link between deposit insurance and the stability of banking systems.

${ }^{3}$ Bank for International Settlement (2002) and World Bank (2005) compile best practice principles for resolving weak financial institutions. Mayes and Liuksila (2004) discuss institutions and policies referring to resolving both systemic and idiosyncratic bank failure.
} 
the transmission of monetary policy may justify special insolvency rules for banks (Benston and Kaufman, 1996).

While the special nature of banking and its importance for market economies justifies a special regulatory, supervisory and insolvency regime, the rules for this regime have to be structured in an incentive-compatible way. Given the call-option character of bank equity, bankers face strong incentives to lend aggressively and take on excessive risks, ignoring prudent risk management (Merton, 1977). The lower their capital base, the less they have to lose and the more they can gain through aggressive lending. Both discipline by creditors and depositors and the regulatory and supervisory framework have an important role to play in checking these incentives. Similarly, the effective and timely intervention and resolution of failing banks is important to minimize aggressive risk taking by banks and thus reduce bank fragility. If bankers know that they face immediate exit combined with the immediate and complete loss of all equity in the case of insolvency, they are less willing to take aggressive risks. If depositors and creditors know that they will suffer losses in the case of bank failure, they will be more willing to exert market discipline. Effective and timely intervention and resolution of failing banks is thus crucial to maintain market discipline and reduce bank fragility. In practice, however, bank authorities are often slow to close banks, allowing for regulatory capital forbearance, particularly in the case of explicit deposit insurance and systemically important banks (see Ronn and Verma (1986) for a model of deposit insurance that incorporates regulatory forbearance). Empirical research shows that in particular during episodes of systemic financial crisis, bank authorities are often reluctant to close banks, resulting in large fiscal costs and a deeper crisis in terms of corporate sector slowdown (Honohan and Klingebiel, 2003, and Claessens, Klingebiel and Laeven, 2003). 
Theory, however, does not provide an unambiguous answer to the question of who should resolve failing banks. In countries with explicit deposit insurance schemes, deposit insurers might be more likely to carefully monitor banks and intervene rapidly into failing banks as they have to carry the costs in terms of higher pay-out to indemnified depositors. However, deposit insurers might also face perverse incentives. First, if the deposit insurance agency is run by the banking industry itself, it might face a conflict of interest in dealing with failing banks. Second, similar as bank supervisors, deposit insurers might have incentives to postpone realization of bank losses to avoid that bank failure "happens on their watch". Third, if the deposit insurer is placed with uninsured depositors in the creditor preference during bankruptcy and ahead of other non-deposit creditors, they might face incentives to intervene too late (Bliss and Kaufman, 2006).

The discussion on the role of the deposit insurance agency in bank failure resolution is also intimately linked to the design and structure of the deposit insurance scheme. On the one hand, the incentive-compatible structure of deposit insurance can be enhanced by a proper alignment of interests. Funding and administration of the deposit insurance scheme by the banking industry can increase the incentives of the deposit insurer to minimize insurance losses. On the other hand, a deposit insurance scheme can only maintain market discipline and minimize moral hazard risks if problem banks are efficiently and timely intervened and resolved. Theory suggests that the possibilities of the deposit insurer to minimize insurance losses can be further enhanced by aligning interests such as by yielding supervisory power to the deposit insurer. This can be taken even further by giving the deposit insurer the authority and responsibility to intervene into problem banks and resolve failing banks. 
In this paper we study empirically the link between the involvement of deposit insurers in bank failure resolution and bank risk. In section 2, we present cross-country indicators of the responsibility of deposit insurers to intervene into banks across 57 countries. We also consider a second indicator, the power of deposit insurer to cancel or revoke the deposit insurance for one of their members. Further, we consider to which extent deposit insurers are independent from political pressure and have access to supervisory information and the interaction of these two institutional features with the role of deposit insurers in bank failure resolution. We enrich the data analysis with a discussion of some specific country cases to illustrate to which extent the institutional variation of deposit insurance and bank failure resolution varies across countries. In section 3, we turn to formal hypothesis testing. Specifically, we regress a measure of bank risk on the indicators introduced in section 2, controlling for other bank-and country traits. Our results indicate the importance of the deposit insurer's role in maintaining bank stability. Banks are more stable, i.e. farther away from insolvency in countries where deposit insurers have a greater role in bank failure resolution. This empirical finding is robust to controlling for other bank and country characteristics, most importantly to controlling for the generosity of deposit insurance and the independence and intervention powers of bank supervisors. However, we also find that this positive effect only takes place if the deposit insurer is politically independent and if it has sufficient access to supervisory information.

This paper is related to a large theoretical and empirical literature on the effect of deposit insurance on banks' risk taking behavior, market discipline and systemic fragility (see Demirguc-Kunt and Kane, 2002, for an overview). Demirgüç-Kunt and Huizinga (2004) find that higher explicit coverage and having a funded scheme reduce market discipline, i.e. the sensitivity of the deposit interest rate the bank has to pay to changes in profits and liquidity 
ratios. Demirgüç-Kunt and Detragiache (2002) likewise find that the probability of having a banking crisis increases in the coverage limit and in having a funded scheme. Hovakimian, Kane and Laeven (2003) show that risk-shifting to the government or subsidization of risk taking is stronger in poor institutional environments but can be reduced with an incentive-compatible design.

Our paper also falls within the broader literature on the optimal design of financial systems and financial sector regulation. Levine (2003) shows that financial systems tend to be dominated either by banks or by markets but that this has no significant impact on economic growth. Jayaratne and Strahan (1995) show that economic growth in U.S. states increased substantially following bank branch deregulation. Barth, Caprio and Levine (2004) collect crosscountry data on an array of regulatory and supervisory practices, including regulations on bank entry, activity restrictions, capital adequacy, loan classification, and provisioning, as well as information about the official power, independence, and resources of bank supervisors and the regulations fostering information disclosure and private-sector monitoring of banks. They find that banking systems with excessive supervision and regulation of banks are less developed and stable than banking systems where markets play an important role in monitoring banks. Similarly, Beck, Demirguc-Kunt and Levine (2006) find that firms face higher obstacles due to corruption in lending in countries with more powerful bank supervisors and less private-sector monitoring. Often political economy factors affect the design of financial systems. Kroszner and Strahan (1999) show that lobbying by interest groups affected the decision to relax bank branching restrictions in the United States, while Kroszner and Stratmann (1998), Kane and Wilson (1998), and Laeven (2002) show that political interest groups affect the design of deposit insurance. 


\section{Deposit insurance and bank failure resolution across countries}

This section introduces several indicators of deposit insurers' involvement in bank failure resolution and the financial safety net in a broader sense. These indicators are constructed from raw data in Barth, Caprio and Levine (2004) and Demirguc-Kunt, Kane, Karacaovali and Laeven (2005). Table 1 presents the variables for the 57 countries in our sample, all countries with explicit deposit insurance schemes, and the Appendix describes the exact definition and source of all variables. We discuss cross-country differences in the institutional set-up of bank failure resolution schemes, especially with respect to deposit insurers' involvement and illustrate with a short discussion of some specific countries.

\subsection{Indicators of deposit insurance and bank failure resolution}

One of the most important institutional questions in bank failure resolution is the responsibility for intervening failing banks. Here we focus on the question whether in countries with explicit deposit insurance the deposit insurer has the authority and responsibility to intervene in a bank (DI Intervention). In ten out of the 57 countries, the deposit insurer has such responsibility; this is the case in such diverse countries as Algeria, Hungary, and the United States.

Almost as significant as the authority to intervene banks is the possibility to revoke membership of banks in the deposit insurance scheme. Does the deposit insurance authority have the legal power to cancel or revoke deposit insurance for any participating bank (DI Power to Revoke)? While revoking membership is certainly not the same as intervening and potentially withdrawing a banking license, the practical effect can be the same, especially if the deposit 
insurer and/or the bank have to inform the public. In 23 countries, the deposit insurer has the right to cancel or revoke membership, including in seven of the ten countries where the deposit insurer has the authority to intervene. Unfortunately, we do not have cross-country information, whether deposit insurers in these 23 countries have actually exercised the right to cancel or revoke deposit insurance before a bank is intervened or the bank license is canceled; evidence from the few countries for which we do have such information, however, suggests that this is a very rare event. So, it must be the threat of revoking rather than the actual action that provides the necessary discipline.

The impact of the power to intervene banks and/or to revoke deposit insurance certainly differs with the degree of independence that deposit insurer enjoys. Deposit insurers that are not politically independent might see abuse of the authority to intervene and revoke membership. We therefore control for the independence of the deposit insurer from political pressure with a dummy variable called DI Independence that takes the value one if the deposit insurance agency is either privately administered or in an independent public agency, and zero otherwise. In 18 countries, the deposit insurer is either privately managed or politically independent, i.e. housed in an institution such as a politically independent Central Bank or bank regulatory authority. Only three of the deposit insurers who have the authority to intervene are also independent. DI Independence is not significantly correlated with either DI Intervention or DI Power to Revoke.

The proper use of the power to intervene and revoke deposit insurance certainly depends on sufficient information about the member banks. We therefore control for the access of the deposit insurer to supervisory information with DI in Supervision, a dummy variable that takes a value of one if the deposit insurance agency is housed inside the bank supervisory agency, and zero otherwise. We note, however, that this is a proxy variable for access to supervisory 
information; as we will discuss below, not all countries where the deposit insurer is housed in the supervisory authority, use this institutional link adequately, while other deposit insurers have access to supervisory information without being housed in the corresponding authority. In 21 countries, the deposit insurer is housed inside the supervisory agency, including in six of the ten countries, where the deposit insurer has the authority to intervene. There is a positive correlation of DI in Supervision with DI Intervention and DI Power to Revoke, but a negative correlation with DI Independence suggesting that deposit insurers are more likely to be housed in the supervisory authority, if the latter is not politically independent.

\subsection{Deposit insurance and bank failure resolution: country examples}

While the four variables introduced in the previous section give a first overview of the variation in deposit insurer's role in bank failure resolution across countries, they are not able to capture the institutional richness of safety net arrangements. We therefore now turn to a brief discussion of some specific countries to illustrate to which extent deposit insurance and bank failure resolution are linked with each other or not. We discuss the following countries for which we have information on safety net arrangements, including bank failure resolution: the United States, Germany, Brazil, Kenya, Uganda, and Bangladesh.

Take first the United States, perhaps the banking system where the link between deposit insurance, bank supervision and bank failure resolution is institutionally strongest. ${ }^{4}$ The Federal Deposit Insurance Corporation (FDIC), a politically independent entity, does not only insure its members' deposits, it is also a bank supervisor and has complete control over the bank failure resolution process, with only ex-post judicial review. The FDIC is either the primary supervisor

\footnotetext{
${ }^{4}$ See Bliss and Kaufman (2006) for a discussion of the U.S. bank resolution system, in comparison with the corporate insolvency system in the United States.
} 
or the back-up supervisor of all banks insured by its fund and has the obligation to intervene in any bank for which it is the primary supervisor and that is "critically undercapitalized", currently defined as a capital to weighted asset ratio of two percent. ${ }^{5}$ The bank resolution process is completely administrative, without court involvement and only some decisions subject to ex-post judicial review and with damages the only available remedy. The FDIC is completely in charge of the process and has to resolve the bank according to the least-cost criterion, i.e. the method that results in the least cost for the deposit insurer. The FDIC's role in bank failure resolution was strengthened to its current form after the banking crisis of the 1990s. While certainly too early to draw any conclusion, its incentive compatible set-up might have contributed to a more stable banking system over the past decade and a half.

Let us now turn to Germany, where there is also a close link between deposit insurance and bank failure resolution, but on an informal and private level (Beck, 2002, 2004). While the data in Table 1 refer to the European Union (EU) mandated limited deposit insurance for all banks, there are several privately-run deposit insurance schemes, among them one for private commercial banks. The deposit insurance fund is managed by the German Bankers Association, which has the right to cancel membership for weak banks, an option it has, however, never exercised. The deposit insurer demands regular audit reports about all its members, can impose corrective actions on basis of these reports, and even impose penalties. While the resolution of failing institutions is the task of the Federal Financial Supervisory Authority as successor of the Federal Bank Supervisory Authority, the resolution has been traditionally undertaken in close informal cooperation with the banking association and creditor banks of the troubled bank. In most cases, a market-based solution, where creditor banks take over the troubled banks or the

\footnotetext{
${ }^{5}$ Other supervisory agencies include the Office of the Comptroller of the Currency, the Thrift Supervisor and state supervisory agencies.
} 
failed bank is sold to a third party with the deposit insurer filling the gap, has been achieved. In at least one case, the initiative for the resolution of a troubled bank was actually initiated by the Banking Association rather than the supervisory authority, testimony to the strong supervisory and monitoring role that the private deposit insurer takes. The private nature of deposit insurance and bank failure resolution has developed over the years out of the club-like nature of the banking system with institutional arrangements designed to enforce mutual monitoring, peer discipline and peer assistance. ${ }^{6}$ While the incentive compatible structure of the German financial safety net might have contributed to banking system stability, there are also concerns of lacking competitiveness stemming from the strong role for incumbent banks in the current system.

Take next Brazil. As in Germany, the deposit insurance agency (FGC) of Brazil is independent and privately managed. ${ }^{7}$ Unlike in Germany, however, the deposit insurance agency FGC is limited to a pay-box function and does not have any involvement in the supervision of its member banks and no role in the resolution of failed banks. The resolution of troubled banks in Brazil is an extrajudicial process, led by interveners and liquidators appointed by the Central Bank. The Central Bank has the power to intervene in problem banks and has different options, including conservatorship and liquidation at its disposal; conservators and liquidators are appointed by the Central Bank. Brazil is thus an example of a banking system where deposit insurance, on the one side, and supervision and failure resolution, on the other side, are institutionally completely separated (Beck, 2004).

Kenya is an example where the deposit insurer seems in a very good position to have a significant role in bank failure resolution. The Deposit Protection Fund (DPF) is housed inside

\footnotetext{
${ }^{6}$ The German deposit insurance scheme resembles the successful insurance schemes in several U.S. states during the $19^{\text {th }}$ and $20^{\text {th }}$ centuries that also relied on peer monitoring and liquidity support during times of distress.

${ }^{7}$ FGC, however, is subject to guidance from the National Monetary Council, a body including the Central Bank governor and the Minister of Finance.
} 
the Central Bank of Kenya, which has also bank supervisory authority, and is in charge of liquidating closed banks. In reality, however, its role is limited. While it shares staff with the Central Bank, it does not have direct access to supervisory information and is not involved at all in supervisory decisions, especially with respect to problem banks. The decision to intervene failing banks is taken by the Central Bank, with approval of the Minister of Finance, a feature that also sheds doubts on the political independence of the Central Bank. The character of deposit insurance as paybox is even stronger in neighboring Uganda, where the deposit insurance fund is administered by the central bank without any separate institutional structure. While the Bank of Uganda (BOU) is also the bank supervisor, the housing of the deposit insurance fund inside the supervisory authority does not seem to provide any incentives for loss minimization.

Bangladesh illustrates how even the absence of bank failure resolution can have an important impact on the efficiency and fragility of banks (Beck and Rahman, 2006). While there is an explicit deposit insurance scheme, housed inside the central bank, Bangladesh Bank, which is also responsible for banking supervision, it has never been used as Bangladesh Bank has never allowed a domestic bank to fail. Rather, weak banks are being referred to the Problem Bank Monitoring Department within Bangladesh Bank where they are subject to special supervisory oversight and certain regulatory restrictions and enjoy regulatory forbearance. There is thus an implicit blanket guarantee for depositors, creditors and even owners of all banks. The lack of exit of failed banks, together with a politicized licensing process, which also shows the lack of political independence of the bank supervisory entity and the still high share of governmentowned banks in the financial system, explains the lack of market discipline in the Bangladeshi banking system. This has resulted in several weak and undercapitalized banks - both government-owned and privately-owned - and inefficient intermediation, as the continuous 
operation of failed banks provides unhealthy competition on the depositor side and distorted incentives for bank-borrower relationships. High spreads and a lack of market-based lending (as opposed to connected or relationship lending) have been explained with these deficiencies.

Is deposit insurance necessary for an effective bank failure resolution scheme? Recent efforts in Latin America have tried to link deposit insurance with a more effective bank failure resolution through the purchase and assumption technique. This technique implies that insured deposits and good assets are carved out and sold to another, performing, bank while impaired assets and non-insured claims on the banks are resolved through liquidation procedures. ${ }^{8}$ Such schemes have been introduced in Argentina, Bolivia, Guatemala and Dominican Republic. This close link between deposit insurance and bank failure resolution through the technique of purchase and assumption seems to imply the necessity of an explicit deposit insurance scheme for effective bank failure resolution.

Are there examples where effective failure resolution has happened without deposit insurance? Consider first Brazil, where the current deposit insurance scheme was introduced as a consequence of the financial crisis of the mid-1990s, when the Central Bank had to resolve several large and medium-sized privately-owned banks. As the constitution prohibits the use of any public funds for depositor compensation, the authorities had to rely on special lines of credit, tax incentives, and regulatory forbearance to resolve the failing banks through intervention and purchase and assumption techniques. ${ }^{9}$ The Central Bank took the leading role in this process, identifying purchasers for troubled banks and providing liquidity support to fill the balance sheet gap. Only in one case was the deposit insurance scheme ex-post involved, while in all other cases, the Central Bank resolved the banks without assistance from deposit insurance. Similarly,

\footnotetext{
${ }^{8}$ The actual technical details can vary significantly, depending on the legal framework in the respective country. See De la Torre (2000) for a discussion.

${ }^{9}$ See Maia (1999) for a detailed discussion.
} 
in South Africa and Mauritius, two other middle-income countries, the authorities have resolved several small banks in recent years without a deposit insurance fund. In some cases, however, public funds were used to facilitate the resolution and compensate depositors. While these cases suggest that authorities can resolve failed banks without an explicit deposit insurance scheme, it also underlines that the institutional structure of the financial safety net cannot be treated out of the context of the overall institutional framework in a country including the moral hazard risk arising from implicit or explicit guarantees provided by the government.

\section{Deposit insurance and bank failure resolution: cross-country regressions}

After having discussed cross-country variation in deposit insurer’s involvement in bank failure resolution, we now turn to empirically testing the relationship between the structure of bank failure resolution scheme and bank fragility. This section first introduces our indicator of bank fragility, presents control variables and methodology, and finally discusses regression results.

\subsection{Indicator of bank stability}

The z-score is a measure of bank stability and indicates the distance from insolvency. It combines accounting measures of profitability, leverage and volatility. Specifically, if we define insolvency as a state where losses surmount equity $(E<-\pi)$ (where $E$ is equity and $\pi$ is profits), $A$ as total assets, $\mathrm{ROA}=\pi / \mathrm{A}$ as return on assets and $\mathrm{CAR}=\mathrm{E} / \mathrm{A}$ as capital-asset ratio, the probability of insolvency can be expressed as prob(-ROA $<$ CAR). If profits are assumed to follow a normal distribution, it can be shown that $\mathrm{z}=(\mathrm{ROA}+\mathrm{CAR}) / \mathrm{SD}(\mathrm{ROA})$ is the inverse of the probability of insolvency. Specifically, $\mathrm{z}$ indicates the number of standard deviation that a 
bank's return on assets has to drop below its expected value before equity is depleted and the bank is insolvent (see Roy, 1952, Hannan and Henwick, 1988, Boyd, Graham and Hewitt, 1993 and De Nicolo, 2000). Thus, a higher z-score indicates that the bank is more stable.

While the z-score has been used widely in the financial and non-financial literature, it is subject to several caveats. ${ }^{10}$ Specifically, it might underestimate banking risk for several reasons. First, it measures risk in a single period of time and does not capture the probability of a sequence of negative profits. Second, it considers only the first and second moment of the distribution of profits and ignores the potential skewness of the distribution (De Nicolo 2000). On the other hand, this measurement bias is less of a concern if it is uniformly distributed across banks and countries. A third concern is the reliance of the z-score on accounting data whose quality might vary across countries. Specifically, several papers have shown the tendency of firms to smooth reported earnings over time and that the degree of earning smoothing varies with the degree of institutional development (see, for example, Leuz, Nanda and Wysocki (2003)). This, however, should bias our results against finding a significant relationship between measures of deposit insurance and bank failure resolution and bank fragility. As an alternative method, other authors have relied on stock market data to compute bank risk as a put option on the value of the bank's assets (Laeven, 2002, and Hovakimian, Kane and Laeven, 2003). Relying on stock market data, however, reduces our sample to a small set of large, listed banks in countries with stock markets, and we therefore decide to use z-scores that can be calculated for all banks instead.

\footnotetext{
${ }^{10}$ Note that this z-score differs from z-score developed by Altman (1968). The Altman z-score is a predictor of corporate financial distress based on financial ratios. The score is derived from a predictive model of a company's probability of default that uses five financial ratios. Altman applied Multiple Discriminant Analysis to determine which financial ratios to include in the predictive model.
} 
We calculate the z-score for a sample of 1,752 banks across 57 countries, with the number of banks included in our sample varying from a high of 315 in the United States and a low of 3 in the Republic of Korea, Oman, Sri Lanka, Sweden and Trinidad and Tobago. ${ }^{11}$ We calculate the return on assets, its standard deviation and the capital-asset ratio over the period 1997-2003. In the regression analysis, we include the log of the z-score to control for non-linear effects and outliers. ${ }^{12}$ Since z-scores might vary with the time period over which they are measured, we will test the sensitivity of our results to the time period over which z-scores are computed. All bank data are from Bankscope, a commercial database of financial statements of financial institutions around the world. While it does not provide a perfect coverage of banks, it usually covers around $90 \%$ of countries’ banking systems in terms of assets.

Table 1 shows a wide variation in bank fragility across countries. Here we present the unweighted average of z-scores across all banks for each country in the sample. The z-scores indicate that for banks' losses to deplete equity, profits have to fall about fifty times below the average level of profits in the United States, but only less than two standard deviations in Korea. The average bank in the average countries has a z-score of 24.

\subsection{Control variables}

We include several bank-level variables to control for bank characteristics that might influence the fragility of individual banks. Specifically, we include the log of total assets in U.S. dollars for the first available year. Larger banks might be better able to diversify risk and thus have more stable earnings, reducing their risk of insolvency. On the other hand, larger banks

\footnotetext{
${ }^{11}$ We imposed a requirement of at least three banks per country. Our results, however, are not affected if we use a broader cross-country sample including countries with data on less than three banks. In order to have a sufficient number of observations to calculate the standard deviation of return on assets over time, we also require at least four years of data for each bank.

${ }^{12}$ All our results are confirmed when we use the level of the z-score.
} 
might take larger risks, especially if they consider themselves too large to fail. Next, we control for the extent to which the bank earns non-interest income using the ratio of other operating income to total revenues. Non-interest income, which includes income from fees, commissions and trading activities, tends to be more volatile than interest income, so we would expect that banks with a larger share of other operating income are less stable and have lower z-scores. We also control for the liquidity of banks by including the ratio of liquid assets to short-term debt, thus controlling for the ability of banks to match debt withdrawable on a short notice with liquid assets (or with assets that can easily be made liquid).

We include several country-level variables in our regressions analysis. Most importantly, we include a measure of the coverage of deposit insurance scheme in terms of average income. Specifically, we relate the coverage limit of deposit insurance to average GDP per capita (Demirguc-Kunt et al., 2004) and refer to this variable as DI Coverage. Demirguc-Kunt and Detragiache (2002) have shown that countries with higher deposit insurance coverage limits are more likely to suffer systemic banking crises. While some countries have low explicit coverage limit, coverage is often extended in the case of systemic failure or even failure of individual banks. Expanding coverage beyond the explicitly insured depositors, however, can negatively impact market discipline and thus increase the moral hazard risk of deposit insurance. In robustness tests, we therefore control for Implicit Coverage, a dummy variable that takes value one if deposit insurance coverage was extended beyond the explicit coverage limit in recent bank failures.

We also include several other country-level variables in order to separate the effect of the financial safety net design from other country characteristics that might influence bank fragility. First, we control for the log of GDP per capita in constant US dollars in 1997 as countries at 
different income levels might be subject to different economic shocks and sources of volatility, which would affect the level and volatility of bank earnings. Second, we control for the growth rate of real GDP per capita and its standard deviation. While faster growing economies might be less subject to bank fragility, higher volatility in economic growth might subject banks to higher fragility. Finally, we control for an indicator of institutional development, constructed by Kaufman, Kraay and Mastruzzi (2003), which is the average of six indicators measuring rule of law, control of corruption, government effectiveness, regulatory quality, political stability and voice and accountability. Controlling for such an encompassing indicator of the institutional framework helps us ensure that our indicators of the financial safety net do not capture the impact of overall institutional quality on bank stability.

\subsection{Methodology}

In order to assess the effect of financial safety net traits on bank stability, we regress the z-score, computed for individual banks over the period 1997-2003, on bank and country characteristics. Our main regression specification is as follows:

$$
\mathrm{Z}_{\mathrm{i}, \mathrm{k}}=\alpha \mathrm{X}_{\mathrm{i}, \mathrm{k}}+\beta \mathrm{Z}_{\mathrm{k}}+\gamma \mathrm{D}_{\mathrm{k}}+\varepsilon_{\mathrm{i}, \mathrm{k}}
$$

where $\mathrm{Z}$ is the $\mathrm{z}$-score of bank $\mathrm{i}$ in country $\mathrm{k}, \mathrm{X}$ is a vector of bank characteristics, $\mathrm{Z}$ is a vector of country characteristics and D is a vector of variables capturing the institutional characteristics of deposit insurance. Although we control for an array of country characteristics, the stability of individual banks within a country might be driven by an omitted factor or might be otherwise correlated with each other. We therefore allow for clustering, i.e. we relax the restrictions that the error terms of banks within a country are independent of each other. 
In the discussion of the results, we will focus on the significance and sign of the coefficients in the vector $\gamma$. A negative coefficient on DI Coverage, the ratio of explicit deposit insurance coverage to GDP per capita, would confirm previous results that more extensive explicit deposit insurance increases the incentives for banks to take aggressive risks. A positive coefficient on DI Intervention and DI Power to Revoke would suggest a positive role for deposit insurers in bank failure resolution to the extent that they help dampen risk taking by banks, while a negative coefficient would indicate a damaging role of deposit insurers in bank failure resolution.

\subsection{Results}

The results in Table 2 suggest that banks are more stable in countries with a more prominent role of the deposit insurer in bank failure resolution. We regress the z-scores of individual banks on DI Coverage, DI Intervention, bank-level control variables and country-level control variables. DI Intervention enters positively and significantly in all regressions, even after controlling for a variety of bank and country characteristics and the coverage limit for deposit insurance. When we evaluate the economic effect at the mean z-score of 24, we find that banks in countries where the deposit insurer has the authority to intervene are on average better able to withstand a fall in profits that is at least six standard deviations higher than banks in countries with no role for the deposit insurer before becoming insolvent. This compares to a standard deviation in z-scores across countries of 14 . When we consider the deposit insurer's right to cancel or revoke a bank’s deposit insurance, we get the same result (column 2).

Consistent with previous research by Demirguc-Kunt and Detragiache (2002), we also find that banks are more fragile in countries with more generous deposit insurance. DI Coverage 
enters negatively and significantly in all but one regression. On the other hand, banks are more stable in countries with more independent and more powerful bank supervisors (columns 3 and 4). Controlling for the generosity of deposit insurance and the role of the deposit insurer in bank failure resolution, we cannot find a significant relationship between the importance of private monitoring in supervision and bank z-scores (column 5). Our measures of the independence and power of bank supervisors and on the degree of private monitoring of banks are from Barth, Caprio and Levine (2001) - see Table A1 for a more detailed definition of these variables.

Turning to the bank- and country-level control variables, we find that banks are significantly more fragile in countries with more volatile GDP per capita growth rates. The other bank- and country-level variables do not significantly and robustly enter the regressions.

Overall, these results confirm the hypothesis that a greater role for the deposit insurer in bank failure resolution can strengthen bank stability by aligning incentives within the financial safety net properly. Deposit insurers have most at stake when banks fail; therefore, giving them higher responsibility within the financial safety net can reduce the negative moral hazard effects of deposit insurance. We next investigate whether this positive impact differs across different institutional settings.

Table 3 shows that the role of deposit insurance in bank failure resolution interacts critically with other elements of the financial safety net. The results in columns 1 and 2 indicate that the positive impact of the intervention power of deposit insurers is strengthened if the deposit insurer is politically independent. While DI Independence enters negatively, but insignificantly, its interaction with DI Intervention enters positively. It is more, as the DI Intervention does not enter significantly anymore, this suggests that the power to intervene only has a positive impact on bank stability if exercised by politically independent deposit insurers. 
Columns 3 and 4 suggest that the positive role of the deposit insurer in bank failure resolution can only be found in countries where the deposit insurance is located in the supervisory agency and thus has direct access to supervisory information. While none of the three variables (DI Intervention, DI in Supervision and their interaction) enter significantly by themselves, DI Intervention is positive and significant if the interaction term is non-zero, i.e. the deposit insurer can intervene and is located in the supervisory authority. ${ }^{13}$ This suggests that (1) the role of the deposit insurer in bank failure resolution has only a positive impact on banks' stability if the deposit insurer is located inside the bank supervisory agency and (2) housing the deposit insurance inside bank supervision has only positive repercussions for bank stability if the deposit insurer is given sufficient tools to discipline its members. The results in columns 5 and 6 suggest that the positive impact of involving deposit insurer in bank failure resolution can be significantly undermined if deposit insurance is extended beyond insured deposits in the case of bank failure. Implicit Coverage enters negatively, but insignificantly in columns 5 and 6, while its interaction with DI Intervention enters positively, but insignificantly in column 6. More importantly, evaluating the effect of DI Intervention if Implicit Coverage equals one yields an insignificant coefficient. Given that DI Intervention enters positively and significantly in columns 5 and 6, this suggests that the positive role of deposit insurers in bank failure resolution only holds if deposit insurance is not extended beyond its explicit limit.

\section{Conclusions}

We study the link between the involvement of deposit insurers in bank failure resolution and bank risk. Using different indicators and discussion of specific countries, we show that there

\footnotetext{
${ }^{13}$ We assess the significance of the sum of the coefficient on DI Intervention and of the coefficient on its interaction with DI in Supervision. The insignificance of the individual terms can be explained by the high correlation of 74 percent between these two variables.
} 
is a wide variation in deposit insurer's role in bank failure resolution. Regression analysis confirms the importance of the deposit insurer's role in maintaining bank stability. We find that banks are more stable in countries where deposit insurers can intervene in banks and/or revoke membership in deposit insurance. This empirical finding is robust to controlling for other bank and country characteristics, including the generosity of deposit insurance and the independence and intervention powers of bank supervisors. We also find important interactions between the powers of deposit insurers and their access to supervisory information; deposit insurers' involvement in bank failure resolution is only beneficial in terms of lower fragility if combined with supervisory oversight. Similarly, housing deposit insurance in bank supervision is only beneficial if it comes with corresponding powers vis-à-vis its members. Deposit insurers are only effective in resolving failed banks and fostering bank stability if they are politically independent. While our results reinforce previous findings that high explicit deposit insurance coverage increases bank fragility, an incentive compatible design can help dampen this negative effect by giving the necessary tools and powers to the deposit insurer to discipline its members and thus minimize insurance losses and bank fragility. Our findings send a strong policy message to countries with existing explicit deposit insurance schemes: strengthening the supervisory capacity and powers of the deposit insurer vis-à-vis its members can have positive implications for bank stability. 


\section{References}

Altman, Edward I. (1968), Financial Ratios, Discriminant Analysis and the Prediction of Corporate Bankruptcy, Journal of Finance 23, 589-609.

Bank for International Settlements (2002), Supervisory Guidance on Dealing with Weak Banks, Basle, Switzerland.

Barth, James, Gerard Caprio, and Ross Levine (2004), Bank Supervision and Regulation: What Works Best? Journal of Financial Intermediation 13, 205-48.

Bartholomew, Philip F. and Benton E. Gup (1997), A Survey of Bank Failures in the non-U.S. G-10 Countries since 1980, unpublished manuscript.

Beck, Thorsten (2002), Deposit Insurance as Private Club: Is Germany a Model? Quarterly Review of Economics and Finance 42, 701-19.

Beck, Thorsten (2004), The Incentive Compatible Design of Deposit Insurance and Bank Failure Resolution - Concepts and Country Studies, in: Who Pays for Bank Insolvency?, David G. Mayes and Aarno Luiksila (eds.), Basingstoke: Palgrave-McMillan.

Beck, Thorsten and Habibur Rahman (2006): Creating a More Efficient Financial System: Challenges for Bangladesh, World Bank Policy Research Working Paper.

Beck, Thorsten, Asli Demirguc-Kunt and Ross Levine (2006), Bank Supervision and Corruption in Lending, Journal of Monetary Economics, forthcoming.

Benston, George, and George Kaufman (1996), The Appropriate Role of Bank Regulation, Economic Journal 106, 688-97.

Bliss, Robert R. and George G. Kaufman (2006), U.S. Corporate and Bank Insolvency Regimes: An Economic Comparison and Evaluation, Federal Reserve Bank of Chicago WP 200601. 
Boyd, John H., Stanley L. Graham and R. Shawn Hewitt (1993), Bank Holding Company mergers with Nonbank Finanical Firms: Effects on the risk of failure, Journal of Banking and Finance 17, 43-63.

Caprio, Gerard, Daniela Klingebiel, Luc Laeven, and Guillermo Noguera (2005), Banking Crisis Database. In: Patrick Honohan and Luc Laeven (Eds.), Systemic Financial Crises: Containment and Resolution. New York: Cambridge University Press, pp. 307-340.

Claessens, Stijn and Leora Klapper (2005), Bankruptcy Around the World: Explanations of its Relative Use. American Law and Economics Review 7, 253-283.

Claessens, Stijn, Daniela Klingebiel and Luc Laeven (2003), Financial Restructuring in Banking and Corporate Sector Crises: What Policies to Pursue? In: Michael Dooley and Jeffrey Frankel (eds.), Managing Currency Crises in Merging Markets. Chicago: University of Chicago Press.

Claessens, Stijn, Simeon Djankov, and Leora Klapper (2003), Resolution of Financial Distress: Evidence from East Asia’s Financial Crisis. Journal of Empirical Finance 10(1-2): 199216.

De la Torre, Augusto (2000), Resolving Bank Failures in Argentina: Recent Developments and Issues, World Bank Policy Research Working Paper 2295.

Demirguc-Kunt, Asli and Enrica Detragiache (2002), Does Deposit Insurance Increase Banking System Stability? An Empirical Investigation, Journal of Monetary Economics 49, 13731406.

Demirguc-Kunt, Asli and Harry Huizinga (2004), Market Discipline and Deposit Insurance, Journal of Monetary Economics 51, 375-399. 
Demirgüç-Kunt, Asli and Edward Kane (2002), Deposit Insurance Around the World: Where Does it Work? Journal of Economic Perspectives 16, 175-195.

Demirguc-Kunt, Asli, Edward Kane, Baybars Karacaovali, and Luc Laeven (2005), Deposit Insurance around the World: A Comprehensive Database, This volume.

De Nicolo, Gianni (2000), Size, Charter Value and Risk in Banking: An International Perspective, International Finance Discussion Papers No. 689, Washington, DC: Board of Governors of the Federal Reserve System.

Diamond, Diamond, and Philip Dybvig (1983), Bank Runs, Deposit Insurance and Liquidity, Journal of Political Economy 91, 401-419.

Gilson, Stuart C., Edith S. Hotchkiss and Richard S. Ruback (2000), Valuation of Bankrupt Firms, Review of Financial Studies 13, 43-74.

Hannan, Timothy H. and Gerald A. Hanweck (1988), Bank Insolvency Risk and the Market for Large Certificates of Deposit, Journal of Money, Credit and Banking 20, 203-11.

Hart, Oliver (2000), Different Approaches to Bankruptcy, NBER Working Paper 7921.

Honohan, Patrick and Daniela Klingebiel (2003), The Fiscal Cost Implications of an Accommodating Approach to Banking Crises, Journal of Banking and Finance 27, 15391560.

Honohan, Patrick and Luc Laeven (Eds.) (2005), Systemic Financial Crises: Containment and Resolution. Cambridge University Press.

Hovakimian, Armen, Edward Kane, and Luc Laeven (2003), How Country and Safety Net Characteristics Affect Bank Risk-Shifting, Journal of Financial Services Research 23, $177-204$. 
Hüpkes, Eva (2004), Insolvency - Why a Special Regime for Banks? Mimeo, Swiss National Bank.

Jayaratne, Jith and Philip E. Strahan (1995), The Finance-Growth Nexus: Evidence from Bank Branch Deregulation, Quarterly Journal of Economics 111, 639-670.

Kane, Edward and Barry K. Wilson (1998), A Contracting-Theory Interpretation of the Origins of Federal Deposit Insurance, Journal of Money, Credit, and Banking 30, 573-595.

Kaufmann, Daniel, Aart Kraay, and Massimo Mastruzzi (2003), Governance Matters III: Governance Indicators for 1996-2002, Policy Research Working Paper 3106, Washington, D.C.: World Bank.

Kroszner, Randall, and Philip Strahan (1999), What Drives Deregulation? Economics and Politics of the Relaxation of Bank Branching Restrictions, Quarterly Journal of Economics 114, 1437-1467.

Kroszner, Randall, and Thomas Stratmann (1998), Interest Group Competition and the Organization of Congress: Theory and Evidence from Financial Services' Political Action Committees, American Economic Review 88, 1163-1187.

Laeven, Luc (2002), Bank Risk and Deposit Insurance, World Bank Economic Review 16, 109137.

Laeven, Luc (2004), The Political Economy of Deposit Insurance, Journal of Financial Services Research 26, 201-224.

Leuz, Christian, D.J. Nanda and Peter Wysocki, (2003). Investor Protection and Earnings Management: An International Comparison, Journal of Financial Economics 69, 505527. 
Levine, Ross (2001), Bank-Based or Market-Based Financial Systems: Which is Better? Journal of Financial Intermediation 11, 1-30.

Mayes, David G. and Aarno Luiksila (2004), Who Pays for Bank Insolvency? Basingstoke: Palgrave-McMillan.

Merton, Robert (1977), An Analytical Derivation of the Cost of Deposit Insurance and Loan Guarantees, Journal of Banking and Finance 1, 3-11.

Maia, Geraldo (1999), Restructuring the Banking System - the Case of Brazil, in: Bank for International Settlement: Bank Restructuring in Practice, BIS Policy Papers No. 6, 106123.

Ronn, Ehud I., and Avinash K. Verma (1986), Pricing Risk-Adjusted Deposit Insurance: An Option-Based Model, Journal of Finance 41, 871-895.

Roy, Andrew D. (1952), Safety First and the Holding of Assets, Econometrica 20, 431-449.

Wihlborg, Clas, Shubhashis Gangopadhyay and Qaizar Hussain (2001), Infrastructure Requirements in the Area of Bankruptcy Law, Wharton Financial Institutions Center Working Paper 01-09.

World Bank (2005), Global Bank Insolvency Initiative: Legal, Institutional, and Regulatory Framework to Deal with Insolvent Banks. Washington, D.C. 
Table 1. Bank stability and bank failure resolution across countries

\begin{tabular}{|c|c|c|c|c|c|}
\hline Country Name & z-score & $\begin{array}{c}\text { DI } \\
\text { Intervention }\end{array}$ & $\begin{array}{l}\text { DI Power to } \\
\text { Revoke }\end{array}$ & $\begin{array}{c}\mathrm{DI} \\
\text { Independence }\end{array}$ & $\begin{array}{c}\text { DI in } \\
\text { Supervision }\end{array}$ \\
\hline Albania & 11.64 & 0 & 1 & 0 & 1 \\
\hline Algeria & 60.22 & 1 & 0 & 0 & 1 \\
\hline Argentina & 6.47 & 0 & 0 & 1 & 0 \\
\hline Austria & 35.27 & 0 & 1 & 1 & 0 \\
\hline Bahrain & 56.46 & 0 & 1 & 0 & 1 \\
\hline Belarus & 9.09 & 1 & 1 & 0 & 1 \\
\hline Belgium & 23.27 & 0 & 0 & 0 & 0 \\
\hline Bosnia \& Herzegovina & 24.33 & 0 & 1 & 0 & 0 \\
\hline Brazil & 13.52 & 0 & 0 & 1 & 0 \\
\hline Bulgaria & 10.62 & 0 & 0 & 0 & 0 \\
\hline Canada & 32.39 & 1 & 1 & 1 & 0 \\
\hline Chile & 18.56 & 0 & 0 & 1 & 0 \\
\hline Colombia & 10.29 & 0 & 0 & 0 & 0 \\
\hline Croatia & 29.40 & 0 & 0 & 0 & 0 \\
\hline Czech Republic & 17.70 & 0 & 0 & 0 & 0 \\
\hline Denmark & 33.20 & 0 & 1 & 1 & 0 \\
\hline El Salvador & 36.88 & 0 & 0 & 0 & 0 \\
\hline France & 31.74 & 0 & 1 & 1 & 0 \\
\hline Germany & 47.99 & 0 & 0 & 1 & 1 \\
\hline Guatemala & 23.27 & 0 & 0 & 0 & 0 \\
\hline Honduras & 20.12 & 0 & 0 & 1 & 0 \\
\hline Hungary & 13.27 & 1 & 1 & 0 & 0 \\
\hline India & 18.35 & 0 & 1 & 0 & 1 \\
\hline Ireland & 37.56 & 0 & 1 & 0 & 1 \\
\hline Italy & 39.47 & 1 & 1 & 1 & 0 \\
\hline Japan & 46.92 & 0 & 0 & 0 & 0 \\
\hline Jordan & 37.48 & 0 & 0 & 0 & 0 \\
\hline Kazakhstan & 10.87 & 0 & 1 & 0 & 1 \\
\hline Kenya & 27.21 & 0 & 1 & 0 & 1 \\
\hline Korea, Rep. & 1.53 & 0 & 0 & 0 & 0 \\
\hline Latvia & 8.54 & 0 & 0 & 0 & 0 \\
\hline Lebanon & 23.38 & 0 & 0 & 0 & 0 \\
\hline Luxembourg & 28.38 & 0 & 1 & 1 & 0 \\
\hline Macedonia, FYR & 16.50 & 0 & 0 & 0 & 0 \\
\hline Mexico & 11.68 & 0 & 0 & 1 & 0 \\
\hline Netherlands & 40.25 & 0 & 0 & 0 & 1 \\
\hline Nicaragua & 10.84 & 0 & 0 & 0 & 0 \\
\hline Nigeria & 11.98 & 0 & 1 & 0 & 0 \\
\hline Norway & 10.11 & 0 & 0 & 1 & 0 \\
\hline Oman & 19.86 & 1 & 1 & 0 & 1 \\
\hline Peru & 17.95 & 0 & 0 & 1 & 0 \\
\hline Philippines & 37.44 & 0 & 1 & 1 & 0 \\
\hline Poland & 13.99 & 0 & 0 & 0 & 0 \\
\hline Portugal & 37.20 & 0 & 0 & 0 & 1 \\
\hline Romania & 8.67 & 0 & 0 & 0 & 0 \\
\hline
\end{tabular}




\begin{tabular}{lccccc}
\hline Country Name & z-score & $\begin{array}{c}\text { DI } \\
\text { Intervention }\end{array}$ & $\begin{array}{c}\text { DI Power to } \\
\text { Revoke }\end{array}$ & $\begin{array}{c}\text { DI } \\
\text { Independence }\end{array}$ & $\begin{array}{c}\text { DI in } \\
\text { Supervision }\end{array}$ \\
\hline Slovak Republic & 16.06 & 1 & 0 & 0 & 0 \\
Slovenia & 41.36 & 1 & 0 & 0 & 1 \\
Spain & 38.63 & 0 & 0 & 0 & 1 \\
Sri Lanka & 5.14 & 0 & 1 & 0 & 1 \\
Sweden & 32.60 & 0 & 1 & 0 & 1 \\
Switzerland & 51.14 & 0 & 1 & 1 & 0 \\
Taiwan, China & 17.69 & 0 & 0 & 0 & 1 \\
Trinidad and Tobago & 23.80 & 0 & 0 & 0 & 1 \\
Ukraine & 9.18 & 1 & 1 & 0 & 1 \\
United Kingdom & 36.19 & 0 & 0 & 1 & 1 \\
United States & 48.84 & 1 & 1 & 1 & 1 \\
Venezuela, RB & 13.30 & 0 & 0 & 0 & 0 \\
\hline
\end{tabular}




\section{Table 2. Bank stability and the design of bank failure resolution}

Dependent variable is the z-score. We report OLS regressions with clustered standard errors between parentheses.. * significant at $10 \%$; ** significant at $5 \%$; *** significant at $1 \%$. For definitions and sources, see table A1.

\begin{tabular}{|c|c|c|c|c|c|}
\hline & (1) & (2) & (3) & $(4)$ & $(5)$ \\
\hline Log total assets & $\begin{array}{l}-0.010 \\
(0.020)\end{array}$ & $\begin{array}{c}0.000 \\
(0.021)\end{array}$ & $\begin{array}{c}-0.007 \\
(0.021)\end{array}$ & $\begin{array}{c}0.004 \\
(0.022)\end{array}$ & $\begin{array}{c}0.006 \\
(0.021)\end{array}$ \\
\hline Liquidity & $\begin{array}{l}-0.004 \\
(0.002)\end{array}$ & $\begin{array}{l}-0.003 \\
(0.003)\end{array}$ & $\begin{array}{l}-0.004^{*} \\
(0.002)\end{array}$ & $\begin{array}{l}-0.004 \\
(0.002)\end{array}$ & $\begin{array}{l}-0.004 \\
(0.002)\end{array}$ \\
\hline Non-interest income & $\begin{array}{l}-0.135^{*} \\
(0.079)\end{array}$ & $\begin{array}{l}-0.144^{*} \\
(0.084)\end{array}$ & $\begin{array}{l}-0.110 \\
(0.075)\end{array}$ & $\begin{array}{l}-0.134 \\
(0.085)\end{array}$ & $\begin{array}{l}-0.115 \\
(0.077)\end{array}$ \\
\hline Log GDP per capita & $\begin{array}{c}0.000 \\
(0.094)\end{array}$ & $\begin{array}{c}0.087 \\
(0.086)\end{array}$ & $\begin{array}{l}-0.009 \\
(0.097)\end{array}$ & $\begin{array}{l}-0.043 \\
(0.093)\end{array}$ & $\begin{array}{l}-0.004 \\
(0.102)\end{array}$ \\
\hline Growth & $\begin{array}{c}0.266 \\
(4.402)\end{array}$ & $\begin{array}{c}-0.359 \\
(3.799)\end{array}$ & $\begin{array}{c}-2.782 \\
(3.713)\end{array}$ & $\begin{array}{c}-4.279 \\
(3.906)\end{array}$ & $\begin{array}{l}-6.026 \\
(4.083)\end{array}$ \\
\hline Volatility & $\begin{array}{c}-14.386^{* *} \\
(6.311)\end{array}$ & $\begin{array}{c}-16.295 * * * \\
(5.479)\end{array}$ & $\begin{array}{c}-18.763^{* * *} \\
(4.502)\end{array}$ & $\begin{array}{c}-20.368 * * * \\
(5.235)\end{array}$ & $\begin{array}{c}-20.207 * * * \\
(5.238)\end{array}$ \\
\hline DI Coverage & $\begin{array}{c}-0.001^{* *} \\
(0.000)\end{array}$ & $\begin{array}{c}-0.001^{* *} \\
(0.000)\end{array}$ & $\begin{array}{c}-0.000 \\
(0.000)\end{array}$ & $\begin{array}{l}-0.000 \\
(0.000)\end{array}$ & $\begin{array}{c}-0.001^{* *} \\
(0.000)\end{array}$ \\
\hline KK Index & $\begin{array}{l}0.339^{*} \\
(0.173)\end{array}$ & $\begin{array}{c}0.176 \\
(0.152)\end{array}$ & $\begin{array}{c}0.264 \\
(0.173)\end{array}$ & $\begin{array}{c}0.399 * * \\
(0.172)\end{array}$ & $\begin{array}{c}0.381^{* *} \\
(0.181)\end{array}$ \\
\hline DI Intervention & $\begin{array}{c}0.314^{* * *} \\
(0.112)\end{array}$ & & $\begin{array}{c}0.231^{* *} \\
(0.102)\end{array}$ & $\begin{array}{c}0.291 * * * \\
(0.096)\end{array}$ & $\begin{array}{c}0.355^{* * *} \\
(0.116)\end{array}$ \\
\hline DI Power to Revoke & & $\begin{array}{c}0.330 * * * \\
(0.102)\end{array}$ & & & \\
\hline Supervisory Independence & & & $\begin{array}{c}0.131^{* * *} \\
(0.041)\end{array}$ & & \\
\hline Supervisory Power & & & & $\begin{array}{c}0.096 * * * \\
(0.034)\end{array}$ & \\
\hline Private Monitoring & & & & & $\begin{array}{l}-0.129 \\
(0.085)\end{array}$ \\
\hline Observations & 1752 & 1752 & 1610 & 1623 & 1623 \\
\hline Number of countries & 57 & 57 & 45 & 46 & 46 \\
\hline R-squared & 0.21 & 0.22 & 0.22 & 0.22 & 0.22 \\
\hline
\end{tabular}


Table 3. Bank stability and the design of bank failure resolution - interaction with other features of the financial safety net

Dependent variable is the z-score. We report OLS regressions with clustered standard errors between parentheses.. * significant at 10\%; ** significant at 5\%; *** significant at 1\%. For definitions and sources, see table A1.

\begin{tabular}{|c|c|c|c|c|c|c|}
\hline & (1) & (2) & (3) & (4) & (5) & (6) \\
\hline Log total assets & $\begin{array}{l}-0.010 \\
(0.021)\end{array}$ & $\begin{array}{l}-0.017 \\
(0.022)\end{array}$ & $\begin{array}{l}-0.016 \\
(0.021)\end{array}$ & $\begin{array}{l}-0.015 \\
(0.021)\end{array}$ & $\begin{array}{l}-0.012 \\
(0.020)\end{array}$ & $\begin{array}{l}-0.012 \\
(0.020)\end{array}$ \\
\hline Liquidity & $\begin{array}{l}-0.004^{*} \\
(0.002)\end{array}$ & $\begin{array}{l}-0.004 * \\
(0.002)\end{array}$ & $\begin{array}{c}-0.004^{* *} \\
(0.002)\end{array}$ & $\begin{array}{l}-0.004^{*} \\
(0.002)\end{array}$ & $\begin{array}{l}-0.004^{*} \\
(0.002)\end{array}$ & $\begin{array}{l}-0.004^{*} \\
(0.002)\end{array}$ \\
\hline Non-interest income & $\begin{array}{l}-0.134 \\
(0.081)\end{array}$ & $\begin{array}{l}-0.130 \\
(0.080)\end{array}$ & $\begin{array}{l}-0.122 \\
(0.076)\end{array}$ & $\begin{array}{l}-0.124 \\
(0.077)\end{array}$ & $\begin{array}{l}-0.141^{*} \\
(0.083)\end{array}$ & $\begin{array}{l}-0.141^{*} \\
(0.083)\end{array}$ \\
\hline Log GDP per capita & $\begin{array}{c}0.003 \\
(0.093)\end{array}$ & $\begin{array}{l}-0.017 \\
(0.090)\end{array}$ & $\begin{array}{c}0.056 \\
(0.099)\end{array}$ & $\begin{array}{c}0.035 \\
(0.102)\end{array}$ & $\begin{array}{c}0.017 \\
(0.092)\end{array}$ & $\begin{array}{c}0.012 \\
(0.091)\end{array}$ \\
\hline Growth & $\begin{array}{l}-0.201 \\
(4.356)\end{array}$ & $\begin{array}{c}0.656 \\
(4.361)\end{array}$ & $\begin{array}{l}-0.177 \\
(4.388)\end{array}$ & $\begin{array}{l}-0.099 \\
(4.395)\end{array}$ & $\begin{array}{l}-0.295 \\
(4.567)\end{array}$ & $\begin{array}{l}-0.253 \\
(4.567)\end{array}$ \\
\hline Volatility & $\begin{array}{c}-14.248^{* *} \\
(6.084)\end{array}$ & $\begin{array}{c}-13.865^{* *} \\
(5.768)\end{array}$ & $\begin{array}{c}-14.486^{* *} \\
(6.262)\end{array}$ & $\begin{array}{c}-14.894^{* *} \\
(6.256)\end{array}$ & $\begin{array}{c}-14.362 * * \\
(5.880)\end{array}$ & $\begin{array}{c}-14.045^{* *} \\
(5.850)\end{array}$ \\
\hline DI Coverage & $\begin{array}{l}-0.001 \\
(0.000)\end{array}$ & $\begin{array}{l}-0.001 \\
(0.000)\end{array}$ & $\begin{array}{c}-0.001^{* *} \\
(0.000)\end{array}$ & $\begin{array}{c}-0.001^{* *} \\
(0.000)\end{array}$ & $\begin{array}{c}-0.001 * * * \\
(0.000)\end{array}$ & $\begin{array}{c}-0.001 * * * \\
(0.000)\end{array}$ \\
\hline KK Index & $\begin{array}{l}0.359 * * \\
(0.174)\end{array}$ & $\begin{array}{l}0.372 * * \\
(0.172)\end{array}$ & $\begin{array}{c}0.239 \\
(0.188)\end{array}$ & $\begin{array}{c}0.270 \\
(0.189)\end{array}$ & $\begin{array}{l}0.317^{*} \\
(0.171)\end{array}$ & $\begin{array}{l}0.328^{*} \\
(0.168)\end{array}$ \\
\hline DI Intervention & $\begin{array}{c}0.325^{* * * *} \\
(0.118)\end{array}$ & $\begin{array}{l}-0.154 \\
(0.238)\end{array}$ & $\begin{array}{l}0.222 * * \\
(0.089)\end{array}$ & $\begin{array}{c}0.082 \\
(0.174)\end{array}$ & $\begin{array}{c}0.285^{* * * *} \\
(0.106)\end{array}$ & $\begin{array}{l}0.265^{* *} \\
(0.127)\end{array}$ \\
\hline DI Independence & $\begin{array}{l}-0.063 \\
(0.145)\end{array}$ & $\begin{array}{l}-0.118 \\
(0.138)\end{array}$ & & & & \\
\hline $\begin{array}{l}\text { DI Intervention * } \\
\text { DI Independence }\end{array}$ & & $\begin{array}{l}0.597^{* *} \\
(0.261)\end{array}$ & & & & \\
\hline DI in Supervision & & & $\begin{array}{l}0.222 * * \\
(0.090)\end{array}$ & $\begin{array}{c}0.151 \\
(0.107)\end{array}$ & & \\
\hline $\begin{array}{l}\text { DI Intervention * } \\
\text { DI in Supervision }\end{array}$ & & & & $\begin{array}{c}0.232 \\
(0.198)\end{array}$ & & \\
\hline Implicit coverage & & & & & $\begin{array}{l}-0.148 \\
(0.093)\end{array}$ & $\begin{array}{l}-0.168 \\
(0.101)\end{array}$ \\
\hline $\begin{array}{l}\text { DI Intervention * } \\
\text { Implicit coverage }\end{array}$ & & & & & & $\begin{array}{c}0.110 \\
(0.132)\end{array}$ \\
\hline Observations & 1752 & 1752 & 1752 & 1752 & 1730 & 1730 \\
\hline Number of countries & 57 & 57 & 57 & 57 & 54 & 54 \\
\hline R-squared & 0.21 & 0.22 & 0.22 & 0.22 & 0.21 & 0.21 \\
\hline
\end{tabular}


Table A1. Variable Definitions and Sources

\begin{tabular}{|c|c|c|}
\hline $\begin{array}{l}\text { VARIABLE } \\
\text { NAME }\end{array}$ & DESCRIPTION & SOURCE \\
\hline \multicolumn{3}{|l|}{$\begin{array}{l}\text { DEPENDENT } \\
\text { VARIABLE }\end{array}$} \\
\hline $\mathrm{Z}$ & $\begin{array}{l}\text { Average } \mathrm{Z}=(\mathrm{roa}+\mathrm{ear}) / \text { sdroa over time for each bank between } 1997 \text { and } 2003 \text {. roa is } \\
\text { return on average assets of a bank calculated as net income divided by the average } \\
\text { total assets during the year; ear is equity adequacy ratio of a bank calculated as the } \\
\text { ratio of Equity to Total Assets; sdroa is the standard deviation of roa over the } \\
\text { sample period of a bank }\end{array}$ & $\begin{array}{l}\text { Bankscope and authors' } \\
\text { calculations }\end{array}$ \\
\hline \multicolumn{3}{|l|}{$\begin{array}{l}\text { BANK LEVEL } \\
\text { VARIABLES } \\
\end{array}$} \\
\hline Log total assets & $\begin{array}{l}\text { Natural logarithm of total assets for each bank, the first available year (1997, if not } \\
\text { 1998) }\end{array}$ & $\begin{array}{l}\text { Bankscope and authors' } \\
\text { calculations }\end{array}$ \\
\hline Liquidity & $\begin{array}{l}\text { Liquid assets to short-term debt ratio for each bank, (short-term debt is deposits and } \\
\text { short-term funding) first available year (1997, if not 1998) }\end{array}$ & $\begin{array}{l}\text { Bankscope and authors' } \\
\text { calculations }\end{array}$ \\
\hline Non-interest income & $\begin{array}{l}\text { Non-interest income/Total operating income for each bank; first available year } \\
\text { (1997, if not 1998) }\end{array}$ & $\begin{array}{l}\text { Bankscope and authors' } \\
\text { calculations }\end{array}$ \\
\hline \multicolumn{3}{|l|}{$\begin{array}{l}\text { COUNTRY LEVEL } \\
\text { VARIABLES }\end{array}$} \\
\hline Log GDP per capita & Natural logarithm of GDP per capita constant 2000 US\$, 1997; if not available 1998 & World Development Indicators \\
\hline Growth & $\begin{array}{l}\text { Average yearly GDP per capita constant local currency growth, 1997-2003, i.e. the } \\
\text { average of the yearly differences between the logarithm of GDP per capita in } \\
\text { constant local currency }\end{array}$ & $\begin{array}{l}\text { World Development Indicators } \\
\text { and authors' calculations }\end{array}$ \\
\hline Volatility & $\begin{array}{l}\text { Standard deviation of yearly GDP per capita constant local currency growth, 1997- } \\
2003\end{array}$ & $\begin{array}{l}\text { World Development Indicators } \\
\text { and authors' calculations }\end{array}$ \\
\hline DI Coverage & Ratio of coverage limit of deposit insurance to GDP per capita & $\begin{array}{l}\text { Demirguc-Kunt, Karacaovali } \\
\text { and Laeven (2005) }\end{array}$ \\
\hline KK Index & $\begin{array}{l}\text { The average of six governance indicators (voice and accountability, political } \\
\text { stability, government effectiveness, regulatory quality, rule of law, and control of } \\
\text { corruption) in } 1998 \text { (higher is better) }\end{array}$ & $\begin{array}{l}\text { Kaufmann, Kraay and } \\
\text { Mastruzzi (2003) }\end{array}$ \\
\hline DI Intervention & $\begin{array}{l}\text { A dummy variable which is equal to one if the deposit insurance authority can make } \\
\text { the decision to intervene a bank. }\end{array}$ & $\begin{array}{l}\text { Barth, Caprio and Levine } \\
\text { (2004) }\end{array}$ \\
\hline DI Power to Revoke & $\begin{array}{l}\text { A dummy variable which is equal to one if the deposit insurance authority has the } \\
\text { legal power to cancel or revoke deposit insurance for any participating bank. }\end{array}$ & $\begin{array}{l}\text { Barth, Caprio and Levine } \\
\text { (2004) }\end{array}$ \\
\hline $\begin{array}{l}\text { Supervisory } \\
\text { Independence }\end{array}$ & $\begin{array}{l}\text { Supervisor independence from political (government) pressure and supervisor } \\
\text { independence from pressure by bank managers (indicator ranges between } 1 \text { and 4) }\end{array}$ & $\begin{array}{l}\text { Barth, Caprio and Levine } \\
\text { (2004) }\end{array}$ \\
\hline Supervisory Power & $\begin{array}{l}\text { Principal component indicator of } 14 \text { dummy variables: } 1 \text {.Does the supervisory } \\
\text { agency have the right to meet with external auditors to discuss their report without } \\
\text { the approval of the bank? } 2 \text {. Are auditors required by law to communicate directly } \\
\text { to the supervisory agency any presumed involvement of bank directors or senior } \\
\text { managers in elicit activities, fraud, or insider abuse? } 3 \text {. Can supervisors take legal } \\
\text { action against external auditors for negligence? } 4 \text {. Can the supervisory authority } \\
\text { force a bank to change its internal organizational structure? } 5 \text {. Are off-balance sheet } \\
\text { items disclosed to supervisors? } 6 \text {. Can the supervisory agency order the bank's } \\
\text { directors or management to constitute provisions to cover actual or potential losses? } \\
\text { 7. Can the supervisory agency suspend the directors' decision to distribute: a) }\end{array}$ & $\begin{array}{l}\text { Barth, Caprio and Levine } \\
\text { (2004) }\end{array}$ \\
\hline
\end{tabular}




\begin{tabular}{|c|c|c|}
\hline $\begin{array}{l}\text { VARIABLE } \\
\text { NAME }\end{array}$ & DESCRIPTION & SOURCE \\
\hline Private Monitoring & $\begin{array}{l}\text { Dividends? b) Bonuses? c) Management fees? 8. Can the supervisory agency } \\
\text { legally declare-such that this declaration supersedes the rights of bank shareholders- } \\
\text { that a bank is insolvent? } 9 \text { Does the Banking Law give authority to the supervisory } \\
\text { agency to intervene that is, suspend some or all ownership rights-a problem bank? } \\
\text { 10. Regarding bank restructuring and reorganization, can the supervisory agency } \\
\text { or any other government agency do the following: a) Supersede shareholder rights? } \\
\text { b) Remove and replace management? c) Remove and replace directors? } \\
\text { Principal component indicator of nine dummy variables that measure whether (1) } \\
\text { bank directors and officials are legally liable for the accuracy of information } \\
\text { disclosed to the public, (2) whether banks must publish consolidated accounts, (3) } \\
\text { whether banks must be audited by certified international auditors, (4) whether 100\% } \\
\text { of the largest } 10 \text { banks are rated by international rating agencies, (5) whether off- } \\
\text { balance sheet items are disclosed to the public, (6) whether banks must disclose } \\
\text { their risk management procedures to the public, (7) whether accrued, though unpaid } \\
\text { interest/principal enter the income statement while the loan is still non-performing } \\
\text { (8) whether subordinated debt is allowable as part of capital, and (9) whether there } \\
\text { is no explicit deposit insurance system and no insurance was paid the last time a } \\
\text { bank failed. }\end{array}$ & $\begin{array}{l}\text { Barth, Caprio and Levine } \\
\text { (2004) }\end{array}$ \\
\hline DI in Supervision & $\begin{array}{l}\text { A dummy variable which is equal to zero if the deposit insurance agency is separate } \\
\text { from the bank supervisory institution and one if it is within the bank supervisory } \\
\text { institution. }\end{array}$ & $\begin{array}{l}\text { Demirguc-Kunt, Karacaovali } \\
\text { and Laeven (2005 }\end{array}$ \\
\hline DI Independence & $\begin{array}{l}\text { A dummy variable which is equal to one if the deposit insurance agency is Private } \\
\text { Monitoring or independent, and zero otherwise. }\end{array}$ & $\begin{array}{l}\text { Demirguc-Kunt, Karacaovali } \\
\text { and Laeven (2005) }\end{array}$ \\
\hline Implicit coverage & $\begin{array}{l}\text { A dummy variable which takes the value one if the answer is "Yes" to the following } \\
\text { question: "Were any deposits not explicitly covered by deposit insurance at the time } \\
\text { of the failure compensated when the bank failed (excluding funds later paid out in } \\
\text { liquidation procedures)?", and zero otherwise. }\end{array}$ & $\begin{array}{l}\text { Barth, Caprio and Levine } \\
\text { (2004) }\end{array}$ \\
\hline
\end{tabular}

